\title{
The Use of Sheet Glass Powder as Fine Aggregate Replacement in Concrete
}

\author{
M. Mageswari ${ }^{1, *}$ and Dr. B.Vidivelli ${ }^{2}$ \\ ${ }^{I}$ Research Scholar, Structural Engineering, Annamalai University, Annamalai nagar, 600 002, Tamilnadu, India \\ ${ }^{2}$ Professor of Structural Engineering, Annamalai University, Annamalai nagar, 600 002, Tamilnadu, India
}

\begin{abstract}
Sheet glass powder (SGP) used in concrete making leads to greener environment. In shops, near by Chidambaram many sheet glass cuttings go to waste, which are not recycled at present and usually delivered to landfills for disposal. Using SGP in concrete is an interesting possibility for economy on waste disposal sites and conservation of natural resources. This paper examines the possibility of using SGP as a replacement in fine aggregate for a new concrete. Natural sand was partially replaced $(10 \%, 20 \%, 30 \%, 40 \%$ and $50 \%$ ) with SGP. Compressive strength, Tensile strength (cubes and cylinders) and Flexural strength up to 180 days of age were compared with those of concrete made with natural fine aggregates. Fineness modulus, specific gravity, moisture content, water absorption, bulk density, \%voids, \% porosity (loose and compact) state for sand (S) and SDA were also studied. The test results indicate that it is possible to manufacture concrete containing Sheet glass powder (SGP) with characteristics similar to those of natural sand aggregate concrete provided that the percentage of SGP as fine aggregate is limited to $10-20 \%$, respectively.
\end{abstract}

Key Words: Sheet glass powder, Mechanical properties, Fineness Modulus, Bulk density, Moisture content.

\section{INTRODUCTION}

During the last decades it has been recognized that Sheet Glass waste is of large volume and is increasing year by year in the Shops, construction areas and factories. Using waste glass in the concrete construction sector is advantageous, as the production cost of concrete will go down [1]. Waste glasses are used as aggregates for concrete [2-4]. In Chennai there is a place called Chidambaram where most of the colored sheet glasses from windows are packed as a waste and sent to landfill. The plain sheet glasses can be recycled, but it is costly to remove the color of colored glasses and recycle again. Estimated cost for housing is more and some construction materials like natural sand are also becoming rare [5]. Attempts have been made for a long time to use waste glasses as an aggregate in concrete, but it seems that the concrete with waste glasses always cracks [2, 6]. Very limited work has been conducted for the use of ground glass as a concrete replacement [7]. These waste storage disposals are becoming a serious environmental problem especially for Chidambaram where place disposal sites are lacking. Hence there is a need for recycling more and more waste materials.

The most widely used fine aggregate for the making of concrete is the natural sand mined from the riverbeds. However, the availability of river sand for the preparation of concrete is becoming scarce due to the excessive nonscientific methods of mining from the riverbeds, lowering of water table, sinking of the bridge piers, etc. are becoming common

*Address correspondence to this author at the Research Scholar, Structural Engineering, Annamalai University, Annamalai nagar, 600 002, Tamilnadu, India; Tel: 9942365816; E-mail: mag_rajabishek@ rediff.com treats [5]. The present scenario demands identification of substitute materials for the river sand for making concrete. Recently, some attempts have been made to use ground glass as a replacement in concrete [8-10]. The objective of this paper is to present the results of experimental investigations on Physical and Mechanical properties of concrete made with Sheet Glass powder concrete. Natural fine aggregate is substituted by weight by Sheet Glass Powder at rates varying from 10, 20, 30, 40 and 50 percentages. Compressive, Tension, and flexural strength are evaluated and compared up to 180 days of ages. Specific Properties of concrete materials and Sheet Glass Powder are also studied.

\section{MATERIALS AND METHODS}

The raw materials, used for this study are natural coarse aggregate, fine aggregate, Sheet glass Powder (SGP) aggregate and 53 grades Portland cement. The Sheet glass used for this study was collected from the points in Chidambaram taluk at Cuddalore District. Sheet Glass is converted into fine aggregate as shown in flowchart Fig. (1) and the procedure for making Sheet Glasscrete is shown in flowchart Fig. (2). Sheet Glass collected from shops is shown in Fig. (3), Sheet Glass crushed is shown in Fig. (4) and Sheet glass powder is shown in Fig. (5). Sheet glass Powder using sieve size from $4.75 \mathrm{~mm}$ onwards is shown in Fig. (6). Table 1 shows the Fineness Modulus results of S, SGP, $(\mathrm{S}+10 \% \mathrm{SGP}),(\mathrm{S}+$ $20 \%$ SGP $),(\mathrm{S}+30 \% \mathrm{SGP}),(\mathrm{S}+40 \% \mathrm{SGP})$ and $(\mathrm{S}+50 \% \mathrm{SGP})$. Fig. (3) shows the Fine aggregate material of grading curve and also SGP, (S+10\%SGP), (S+20\%SGP), (S+30\%SGP), $(\mathrm{S}+40 \% \mathrm{SGP})(\mathrm{S}+50 \% \mathrm{SGP})$ and $100 \% \mathrm{SGP}$. The sand used for the study was locally available river sand conforming to grading zone III of IS:383-1970. The coarse aggregate was a 


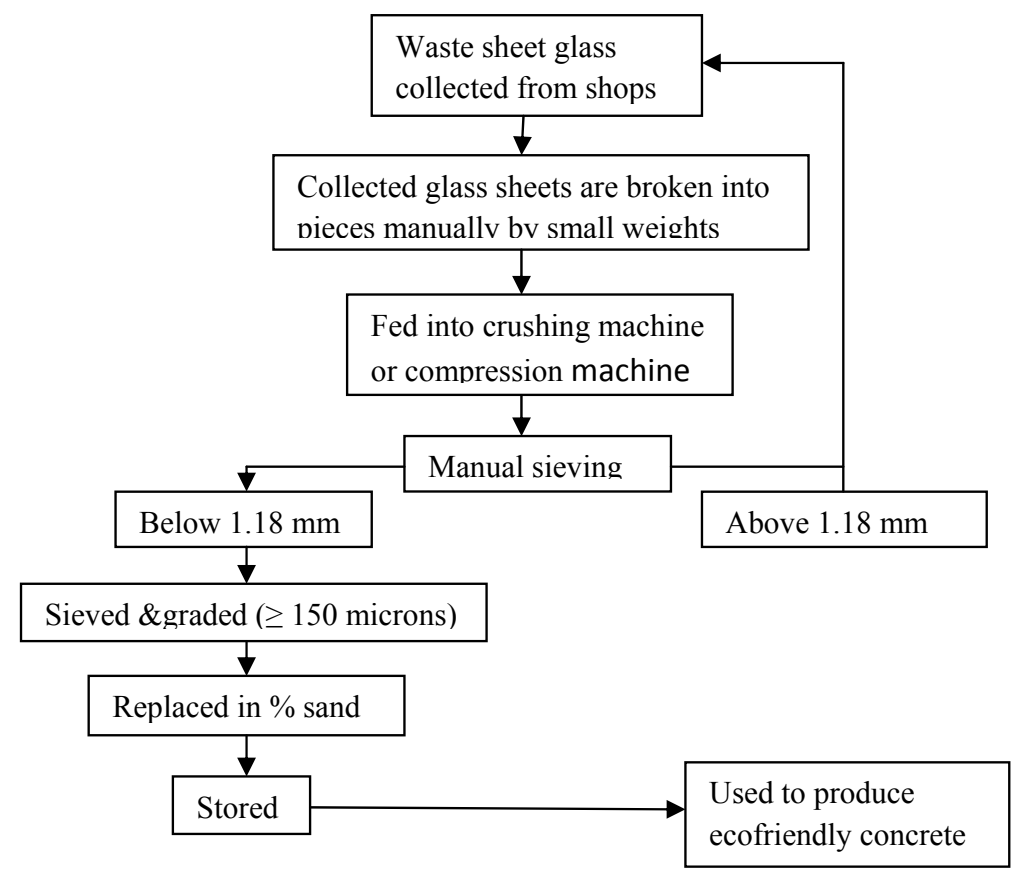

Fig. (1). Shows the Flowchart procedure for grinding sheet glass into sheet glass fine aggregate.

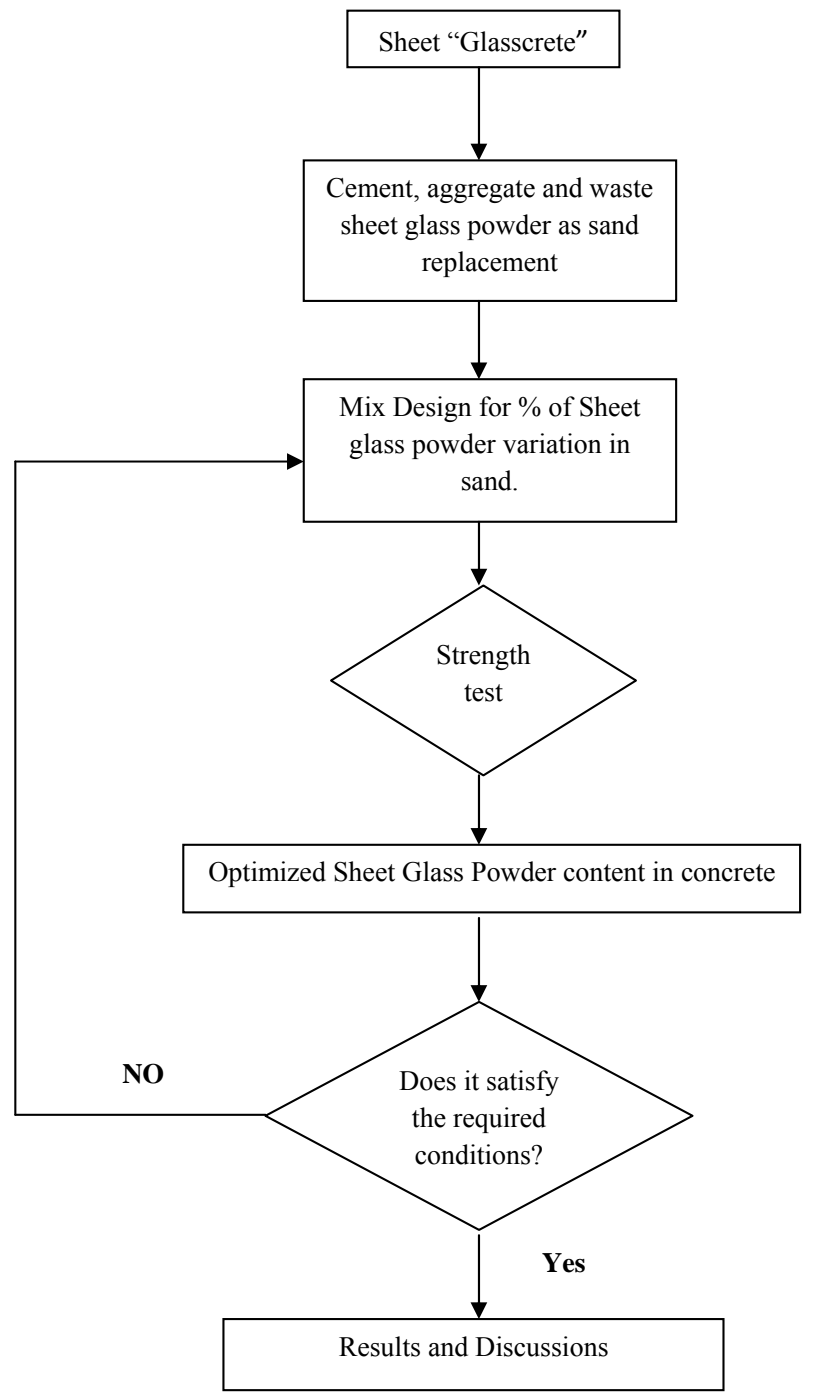

Fig. (2). Shows the Flowchart procedure for making suitable sheet glasscrete. 


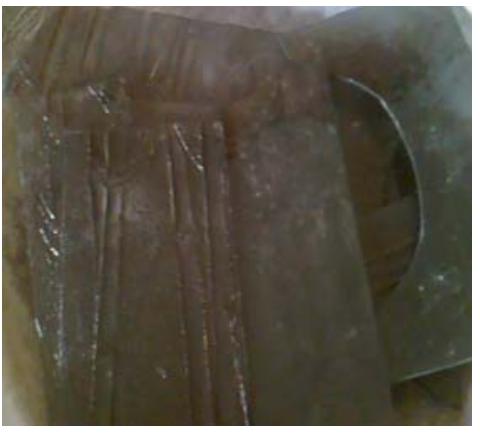

Fig. (3). sheet glass

\begin{tabular}{|l|c|}
\hline Material & $\begin{array}{l}\text { Fineness } \\
\text { Modulus }\end{array}$ \\
\hline Sand (S) & 2.21 \\
\hline SGP & 2.16 \\
\hline$(90 \% \mathrm{~S}+10 \% \mathrm{SGP})$ & 2.25 \\
\hline$(80 \% \mathrm{~S}+20 \% \mathrm{SGP})$ & 1.98 \\
\hline$(70 \% \mathrm{~S}+30 \% \mathrm{SGP})$ & 1.97 \\
\hline$(60 \% \mathrm{~S}+40 \% \mathrm{SGP})$ & 1.84 \\
\hline$(50 \% \mathrm{~S}+50 \% \mathrm{SGP})$ & 1.82 \\
\hline
\end{tabular}

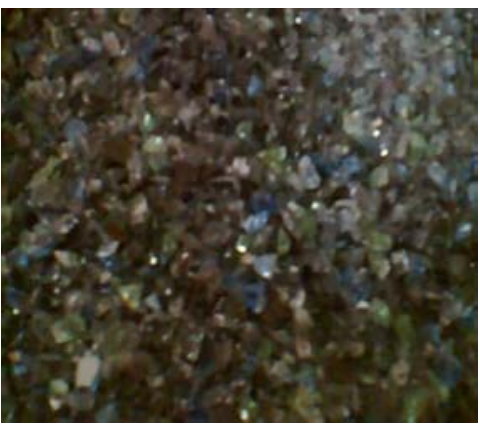

Fig. (4). Crushed sheet glass

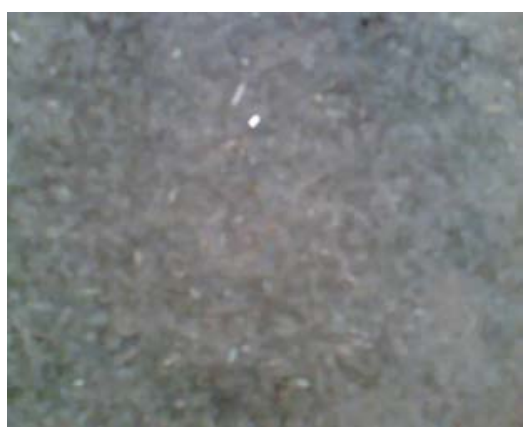

Fig. (5). sheet glass powder

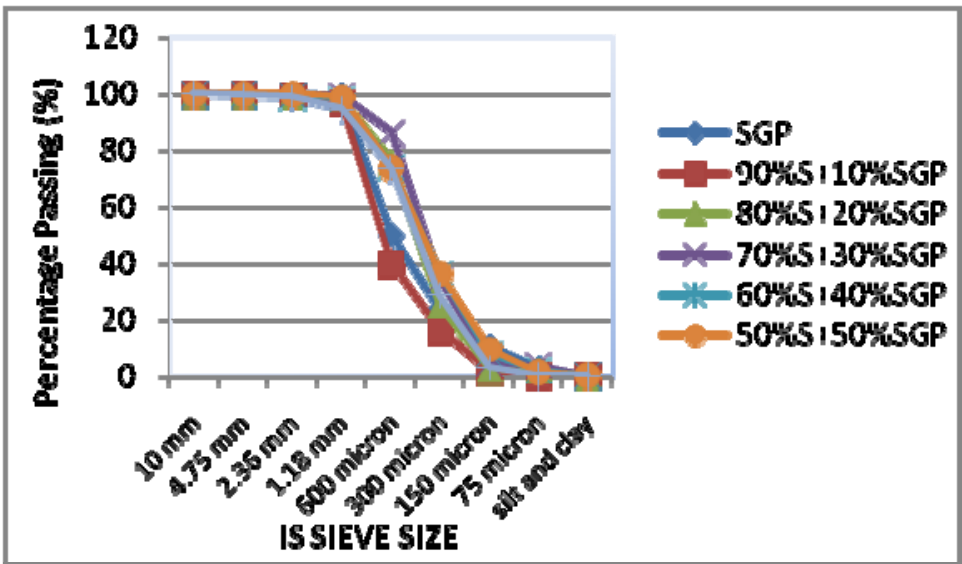

Fig. (6). Sieve Analysis of the Materials.

Table 1. Fineness Modulus

\begin{tabular}{|c|c|c|c|c|c|c|c|c|}
\hline Parameter & Sand & Coarse & SGP & $\begin{array}{c}(90 \% \mathrm{~S}+ \\
10 \% \mathrm{SGP})\end{array}$ & $\begin{array}{c}(80 \% \mathrm{~S}+ \\
20 \% \text { SGP })\end{array}$ & $\begin{array}{c}(70 \% \mathrm{~S}+ \\
30 \% \mathrm{SGP})\end{array}$ & $\begin{array}{c}(60 \% \mathrm{~S}+ \\
40 \% \mathrm{SGP})\end{array}$ & $\begin{array}{c}(50 \% \mathrm{~S}+ \\
50 \% \mathrm{SGP})\end{array}$ \\
\hline Specific gravity & 2.65 & 2.7 & 3.01 & 3.27 & 3.27 & 3.22 & 3.15 & 3.14 \\
\hline Water absorption $\%$ & 8.3 & 0.45 & 1.5 & 6.9 & 5.8 & 5.0 & 4.5 & 4.2 \\
\hline Moisture content $\%$ & 3.70 & 0 & 0.5 & 2.57 & 2.4 & 2.2 & 2.0 & 2.0 \\
\hline$\%$ Voids & 40.8 & 39 & 57 & 53 & 54 & 52 & 51 & 52 \\
\hline$\%$ Porosity & 28.9 & 27 & 36 & 34 & 35 & 34 & 33 & 34 \\
\hline Bulk density (dry compact state) $\left(\mathrm{kg} / \mathrm{m}^{3}\right)$ & 1512 & 1640 & 1530 & 1620 & 1650 & 1700 & 1700 & 1690 \\
\hline Elongation Index & - & 9.61 & - & - & - & - & & \\
\hline
\end{tabular}

Table 2. Physical Properties of Materials

\begin{tabular}{|c|c|c|c|c|c|c|c|c|}
\hline Oxide & $\mathrm{SiO}_{2}$ & $\mathrm{~A}_{2} \mathrm{O}_{3}$ & $\mathrm{Fe}_{2} \mathbf{O}_{3}$ & $\mathrm{CaO}$ & $\mathrm{MgO}$ & $\mathrm{SO}_{3}$ & $\mathrm{LOI}$ & $\mathrm{Na}_{2} \mathrm{O}+\mathrm{K}_{2} \mathrm{O}$ \\
\hline \hline Percentage by mass & 72 & 2 & 0.1 & 13 & 0.7 & 0.09 & 0.22 & 0.11 \\
\hline
\end{tabular}


normal weight aggregate with a maximum size of $20 \mathrm{~mm}$ IS: 456-2000. Table 2 shows the physical properties of SGP and Fine and coarse aggregate. Table 3 shows chemical characteristics of the SGP material. The control mix of the concrete was designed with a mix ratio of cement /water /Sand /Coarse of 1:0.48:1.66:3.61 by weight. This mix design yielded an average 28 days compressive strength $41 \mathrm{Mpa}$. The sand was replaced with $10 \%, 20 \%, 30 \%, 40 \%$, and $50 \%$ SGP.

Table 3. Chemical Analysis of SGP

\begin{tabular}{|c|c|}
\hline Material & Fineness Modulus \\
\hline \hline Sand (S) & 2.21 \\
\hline SGP & 2.16 \\
\hline$(90 \% \mathrm{~S}+10 \% \mathrm{SGP})$ & 2.25 \\
\hline$(80 \% \mathrm{~S}+20 \% \mathrm{SGP})$ & 1.98 \\
\hline$(70 \% \mathrm{~S}+30 \% \mathrm{SGP})$ & 1.97 \\
\hline$(60 \% \mathrm{~S}+40 \% \mathrm{SGP})$ & 1.84 \\
\hline$(50 \% \mathrm{~S}+50 \% \mathrm{SGP})$ & 1.82 \\
\hline
\end{tabular}

\section{EXPERIMENTAL PROGRAMME}

The SG (Sheet Glass) was collected from shops in Chidambaram and its properties were tested. Analysis was carried out in Concrete mixtures with 7 levels of SGP (Sheet Glass Powder) replacement ranging from $10 \%$ to $50 \%$ and $100 \%$. The specimens were cast and tested to study the possibility of using SGP as a substitute material for sand in concrete. The control mix, utilizing SGP, replaced as the fine aggregate, was designed for the cube, cylinder and beam. Based on the laboratory trials, the mix proportion of the control mix $\left(\mathrm{M}_{20}\right)$ was finalized and investigated to determine the effect on compressive and tensile strength in cubes and cylinder. The mixture were $0 \%, 10 \%, 20 \%, 30 \%$, $40 \%, 50 \%$ and $100 \%$ with different Sheet glass powder (SGP) replacement in fine aggregate is analyzed. It is also used to investigate the effect of SGP replacement on Flexural strength.

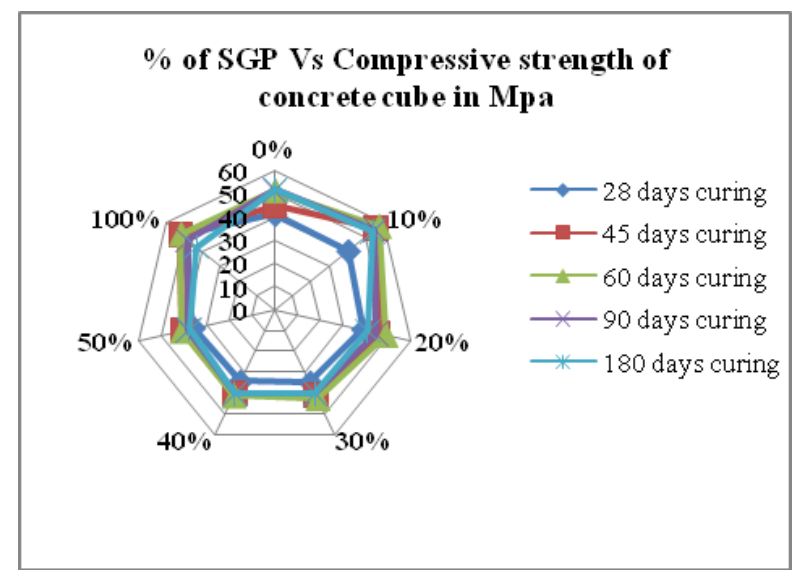

Fig. (7). Compressive strength of concrete cubes.
Tests to determine specific gravity, moisture content, water absorption, Bulk density, Compressive and Tensile strength of cubes and cylinders, SGP was used to replace 0 to $50 \%$ and $100 \%$ of the sand by weight. For compressive and tensile strength tests $150 \times 150 \mathrm{~mm}$ cubes and $150 \mathrm{x}$ $300 \mathrm{~mm}$ cylinders specimens were used. A total of 500 specimens were cast and cured in water at room temperature in the laboratory for $28,45,60,90,180$ days. At the end of each curing period, three specimens for each mixture were tested for Compressive, Tensile and Flexural strength and the average was recorded.

Flexural strength was measured using 100x100x500 mm beam specimen in the centre of the beam load applied. A total of 90 beams were cast and cured in water for 28,45,60, 90,180 days. For each mixture, three beams were loaded to failure, and the average strength was recorded in each case.

\section{RESULTS AND DISCUSSION}

Workability of the concrete increased as the percentages of SGP replacement increased, but it later decreases as the curing days increases because of alkali silica reaction. The density of the concrete $2531 \mathrm{~kg} / \mathrm{m}^{3}$ at $0 \%$ replacement of SGP decreased but at $100 \%$ the density increased to 2689 $\mathrm{kg} / \mathrm{m}^{3}$ for cube at 28 days curing.

\section{Compressive Strength}

The compressive strength test results for the concretes containing SGP as fine aggregates of cubes according to their age are very similar to each other. Thus, the results are presented in Fig. (7) and Fig. (9). Concretes containing SGP as fine aggregates, with a mixing ratio of $30 \%, 40 \%$ and $50 \%$ displayed a reduction in compressive strength than that of plain concrete respectively. This tendency towards a decrease in compressive strength with an increase in mixing ratio was repeated for concretes 180 days of age. At $10 \%$, $20 \%$ and $100 \%$ mixing ratio there was increase in strength than that of plain concrete. In any case, the SGP as fine aggregate in concrete showed a decrease in strength as the curing days increased but at $10 \%$ and $100 \%$ the strength as concrete is more than that of conventional concrete. Fig. (8) and Fig. (10) show the increase in the density of concrete cubes and cylinders as the SGP increases in percentages.

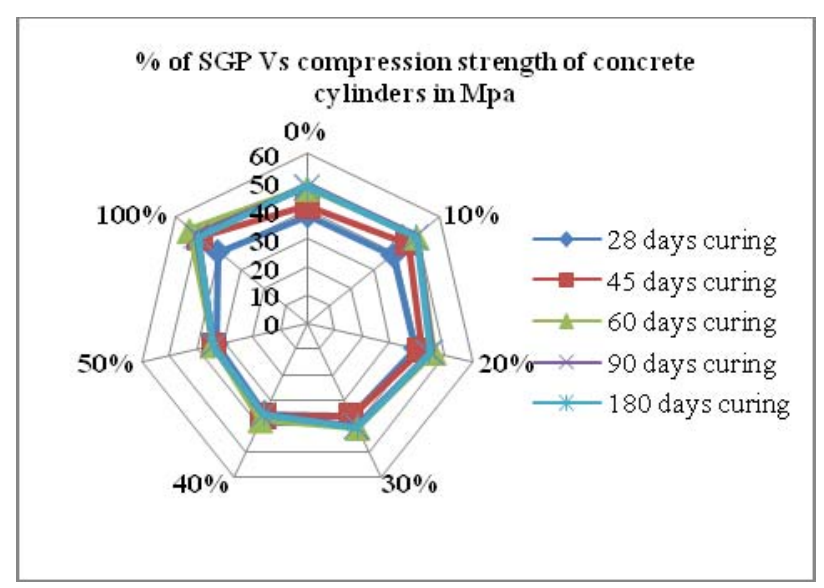

Fig. (8). Compressive strength of Concrete cylinders. 


\section{Tensile Strength}

The Tensile strength test results for the concretes containing SGP fine aggregates of cubes and cylinders according to their age are very similar to each other up to $20 \%$ replacement. Thus, the results are presented in Fig. (11) and Fig. (12). Concretes containing SGP as fine aggregates, with a mixing ratio of $30 \%, 40 \%$ and $50 \%$ displayed an increase in Tensile strength than that of plain concrete as the curing days increase respectively. This tendency towards a decrease in tensile strength with an increase in mixing ratio was re-

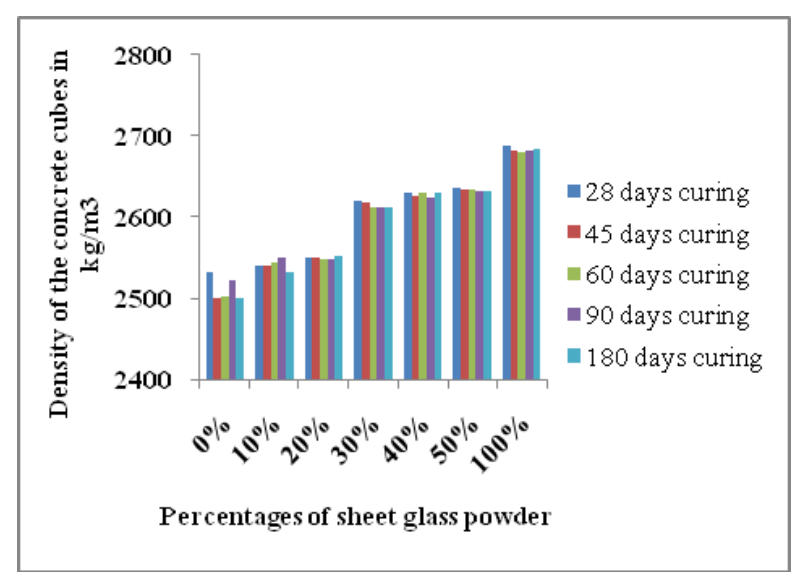

Fig. (9). Density of concrete cubes.

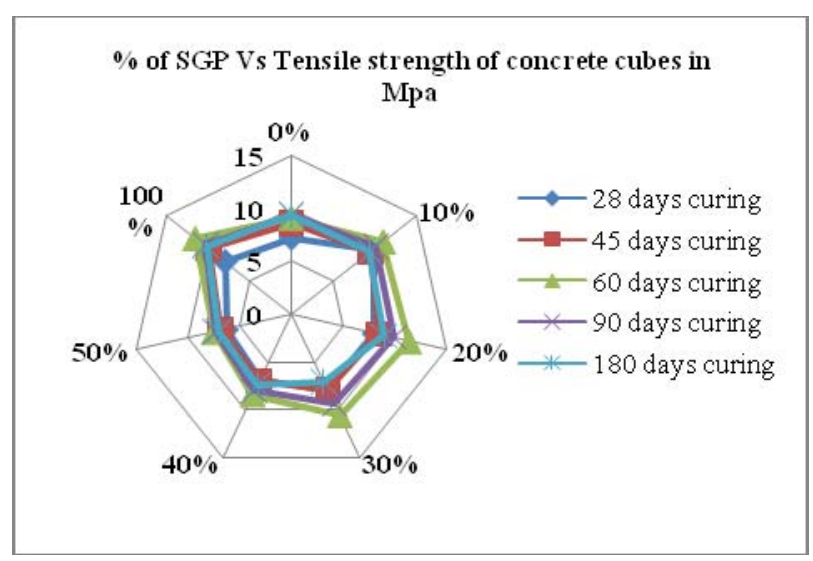

Fig. (11). Tensile strength of Concrete cubes. peated for concretes 180 days of age. At $10 \%$ and $100 \%$ mixing ratio there was an increase in strength than that of plain concrete. In any case, the SGP as fine aggregate in concrete did not have any notable effect on the compressive strength of the concrete.

\section{Flexural Strength}

The Flexural strength test results for the curing concretes with SGP of different percentage according to their age are presented in Fig. (13). The results were very similar to each

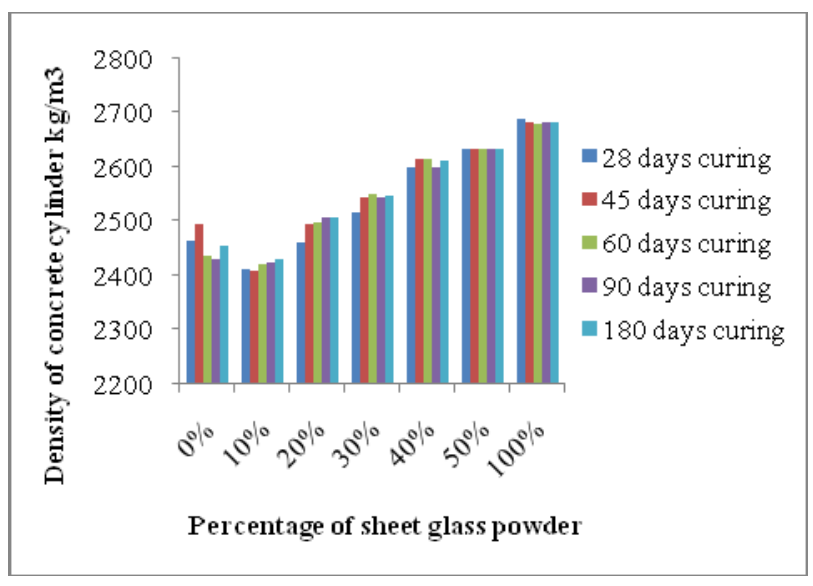

Fig. (10). Density of concrete cylinders.

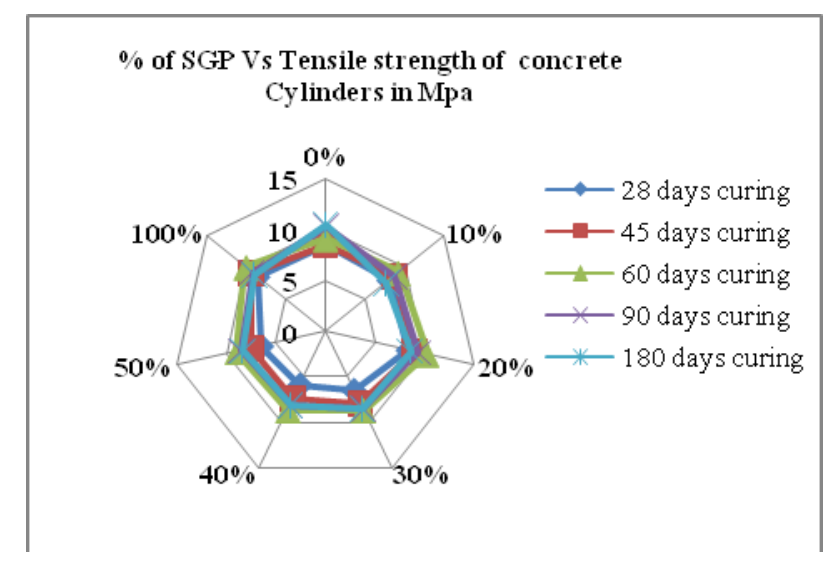

Fig. (12). Tensile strength of Concrete cylinders.

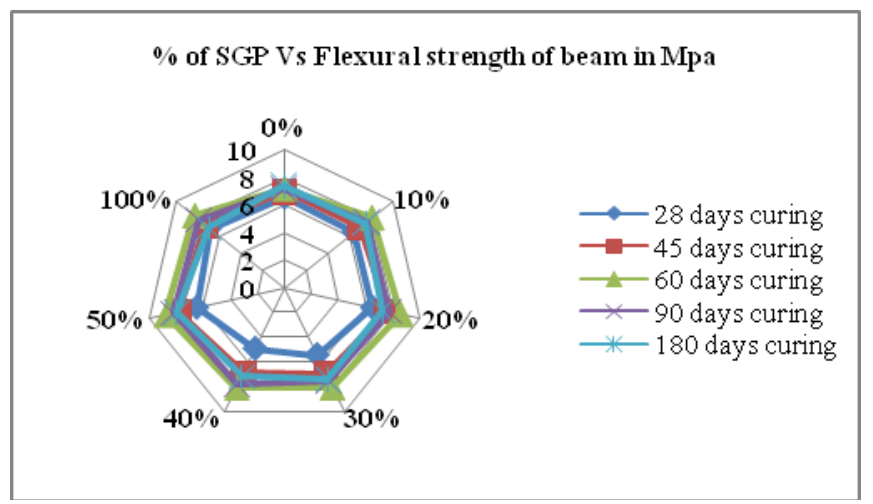

Fig. (13). Flexural strength of the concrete beams. 


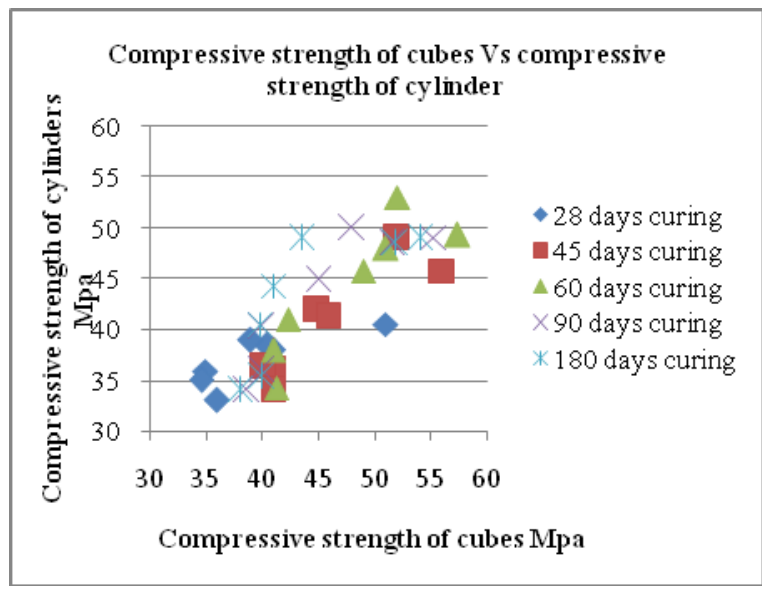

Fig. (14). Compressive strength of cubes Vs.

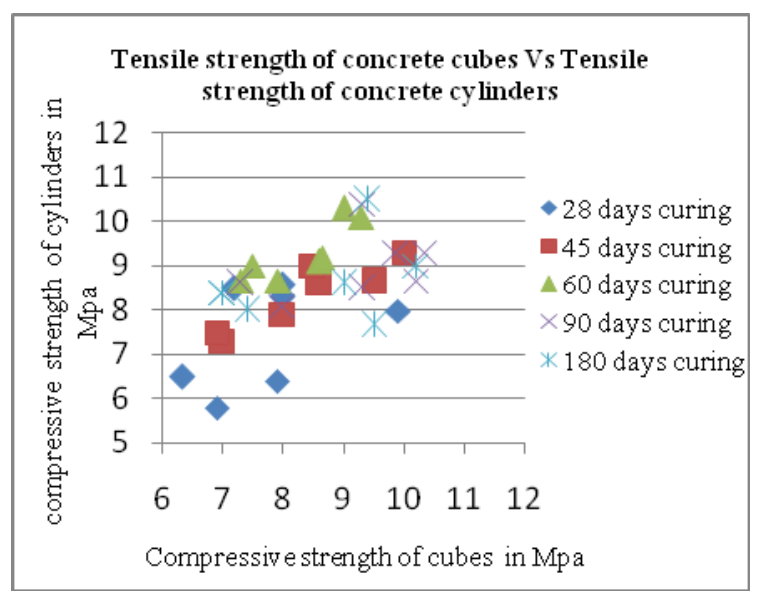

Fig. (15). Tensile strength of cubes Vs Compressive strength of cylinder Tensile strength of cylinder

Table 4. Regression Equations

\begin{tabular}{|c|c|c|c|c|c|}
\hline Curing Days & Regression Equation & $\mathbf{R}^{2}$ & Curing Days & Regression Equation & $\mathbf{R}^{2}$ \\
\hline 28 days & $y=0.466 x+3.818$ & 0.211 & 28 days & $y=0.369 x+22.52$ & 0.644 \\
\hline 60 days & $y=0.726 x+3.241$ & 0.709 & 60 days & $y=0.934 x+0.369$ & 0.783 \\
\hline 90 days & $y=0.274 x+6.457$ & 0.169 & 90 days & $y=0.912 x+1.755$ & 0.796 \\
\hline
\end{tabular}

other like compressive and tensile strength test results. The concrete containing SGP as fine aggregate, at a 10-20\% mixing ratio, showed a slight increase in the flexural strength while that of plain concrete. At $30 \%, 40 \%, 50 \%$ and $100 \%$ mixing ratio there was increase in strength than that of plain concrete.

Fig. (14) shows details of the relationship between the compressive strength of cubes and compressive strength of cylinders of the concretes containing the SGP as fine aggregate and Table 3 gives the details of regression equations and its $\mathrm{R}^{2}$. Fig. (15) explains the relationship between tensile strength of cubes and the tensile strength of cylinders of the concrete containing SGP as fine aggregate and Table $\mathbf{4}$ gives the details of regression equations.

\section{CONCLUSION}

From the tests conducted on SGP replaced in fine aggregate for concrete as presented in various sections, the following conclusions are made:

The SGP is suitable for use in concrete making. The fineness modulus, specific gravity, moisture content, uncompacted bulk density and compacted bulk density at $10 \%$ Sheet glass powder (SGP) were found to be $2.25,3.27,2.57 \%, 1510 \mathrm{~kg} / \mathrm{m}^{3}$ and $1620 \mathrm{~kg} / \mathrm{m}^{3}$ For a given mix, the water requirement decreases as the SGP content increases. The compressive strength of cubes and cylinders of the concrete for all mix increases as the \% of SGP increases but decreases as the age of curing increases due to alkali silica reaction. The Tensile strength of cubes and cylinders of the concrete for all mix increases than that of conventional concrete age of curing and decreases as the SGP content increases. The Flexural strength of the beam of concrete for all mix increases with age of curing and decreases as the SGP content increases. $100 \%$ replacement of SGP in concrete showed better results than that of conventional concrete at 28 days and 45 days curing but later it started to decrease its strength because of its alkali silica reactions. The density of SGP concrete is more that of conventional concrete. SGP is available in significant quantities as a waste and can be utilized for making concrete. This will go a long way to reduce the quantity of waste in our environment. The optimum replacement level in fine aggregate with SGP is $10 \%$.

\section{REFERENCES}

[1] I. B. Topcu, M. Canbaz, "Properties of concrete containing waste glass," Cem. Concr. Res., vol. 34, pp. 267-274, February 2004.

[2] C. D. Johnston, "Waste glass as coarse aggregate for concrete," J. Test. Eval., vol. 2, pp. 344-350, May 1974.

[3] O. Masaki, "Study on hydration hardening character of glass powder and basic physical properties of waste glass as construction material," Asahi Ceram. Found. Annu. Tech. Rep., 1995.

[4] S.B. Park, "Development of recycling and treatment technologies for construction wastes," Minist. Constr. Transp., Seoul, Tech. Rep., 2000.

[5] Job Thomas, "Utilization of quarry powder as a substitute for the river sand in concrete", J. Struct. Eng., vol.32, no.5, pp. 401-407, January 2006.

[6] C. Meyer, and S. Baxter, "Use of recycled glass and fly ash for precast concrete," NYSERDA Rep., vol.1, pp. 98-18, October 1998. 
[7] Y. Shao, T. Lefort, S. Moras, and D. Rodriguez, "Studies on concrete containing ground waste glass," Cem. Concr. Res., vol. 30, no. 1, pp. 91-100, June 2000.

[8] A.Shayan, and A. Xu, "Value - Added Utilization of waste glass in Concrete," Cem. Concr. Res., vol. 34, no.1, pp. 81-89, May 2004.
[9] W. Jin, C. Meyer, and S. Baxter, "Glascrete - Concrete with glass aggregate," ACI. Mater. J., vol. 2, pp. 208-213, May 2000.

[10] C. Polley, S.M. Cramer, and R.V. Crug, "Potential for using waste glass in Portland Cement Concrete," J. Mater. Civil Eng., vol. 10, no. 4, pp. 210-219, May 1998

Received: April 01, 2009

Revised: July 02, 2009

Accepted: September 08, 2009

(C) Mageswari and Vidivelli; Licensee Bentham Open.

This is an open access article licensed under the terms of the Creative Commons Attribution Non-Commercial License

(http://creativecommons.org/licenses/_by-nc/3.0/) which permits unrestricted, non-commercial use, distribution and reproduction in any medium, provided the work is properly cited. 